\title{
Knowledge of healthcare professionals about breastfeeding and supplementary feeding
}

\author{
Conhecimento sobre aleitamento materno e alimentação complementar dos profissionais de saúde
} Conocimiento sobre lactancia materna y la alimentación complementaria de los profesionales de la salud

\section{Ana Elisa Ramos', Carmen Viana Ramos', Marize Melo dos Santos", Camila Aparecida Pinheiro Landim Almeida', Maria do Carmo de Carvalho e Martins" \\ ' Centro Universitário UNINOVAFAPI. Teresina, Piauí, Brazil. \\ "Universidade Federal do Piauí. Teresina, Piauí, Brazil.}

How to cite this article:

Ramos AE, Ramos CV, Santos MM, Almeida CAPL, Martins MCC. Knowledge of healthcare professionals about breastfeeding and supplementary feeding. Rev Bras Enferm [Internet]. 2018;71(6):2953-60.

DOI: http://dx.doi.org/10.1590/0034-7167-2017-0494

Submission: 08-19-2017_Approval: 03-30-2018

\begin{abstract}
Objective: To analyze the knowledge of breastfeeding (BF) and supplementary feeding (SF) of professionals in the Primary Health Care. Method: Cross-sectional study, with 168 professionals, conducted between June and September 2016. The Kruskal Wallis test was used to compare means of percentage of knowledge about BF and SF, by professional category and contingency testing, for association between variables. Results: From the total of professionals, $39.29 \%$ of them demonstrated good knowledge about BF and $2.38 \%$ about SF; 74.4\% of respondents reported not knowing the program Brazilian Breastfeeding and Feeding Strategy (EAAB - Estratégia Amamenta e Alimenta Brasil). There was a positive association between professionals' level of knowledge about BF and education $(p=0.04)$, occupation $(p=0.05)$ and healthcare in BF $(p=0.04)$. Regarding the level of knowledge about SF, there was association between education $(p<0.01)$ and healthcare in SF $(p=0.04)$. Conclusion: The professionals have greater knowledge about breastfeeding when compared to supplementary feeding.
\end{abstract}

Descriptors: Breast Feeding; Healthy Diet; Child Health; Knowledge; Primary Health Care.

\section{RESUMO}

Objetivo: Analisar o conhecimento sobre aleitamento materno (AM) e alimentação complementar (AC) de profissionais da atenção primária. Método: Estudo transversal, com 168 profissionais, realizado entre junho e setembro de 2016 . Utilizou-se o teste de Kruskal Wallis para comparação entre as médias do percentual do conhecimento sobre AM e AC, por categoria profissional, e o teste de contingência, para associação entre as variáveis. Resultados: 39,29\% dos profissionais demonstraram bom conhecimento sobre AM e 2,38\%, sobre AC; 74,4\% dos entrevistados revelaram que não conheciam o programa Estratégia Amamenta e Alimenta. Houve associação positiva entre nível de conhecimento dos profissionais em AM e escolaridade ( $p$ $=0,04)$, profissão $(p=0,05)$ e assistência em AM $(p=0,04)$. Quanto ao nível de conhecimento em AC, houve associação com escolaridade $(p<0,01)$ e assistência em AC $(p=0,04)$. Conclusão: Os profissionais têm maior conhecimento sobre aleitamento materno quando comparado ao conhecimento em alimentação complementar.

Descritores: Aleitamento Materno; Dieta Saudável; Saúde da Criança; Conhecimento; Atenção Primária à Saúde.

\section{RESUMEN}

Objetivo: analizar el conocimiento sobre la lactancia materna (LM) y la alimentación complementaria (AC) de los profesionales de la atención primaria. Método: estudio transversal, con 168 profesionales, realizado entre junio y septiembre de 2016 . Se utilizó la prueba de Kruskal Wallis para la comparación entre los promedios del porcentaje del conocimiento sobre LM y AC, por categoría profesional, y la prueba de contingencia, para asociación entre las variables. Resultados: el 39,29\% de los profesionales demostraron buen conocimiento sobre LM y el 2,38\%, sobre AC; el 74,4\% de los entrevistados revelaron que no conocían el programa Estratégia Amamenta y Alimenta. La asociación fue positiva entre el nivel de conocimiento de los profesionales en LM y escolaridad $(p=0,04)$, profesión $(p=0,05)$ y asistencia en LM $(p=0,04)$. En cuanto al nivel de conocimiento en AC, hubo 
asociación con escolaridad $(p<0,01)$ y asistencia en AC $(p=0,04)$. Conclusión: Los profesionales tienen mayor conocimiento sobre la lactancia materna cuando se compara al conocimiento en alimentación complementaria.

Descriptores: Lactancia Materna; Dieta Saludable; Salud del Niño; Conocimiento; Atención Primaria de Salud.

CORRESPONDING AUTHOR Ana Elisa Ramos E-mail: anaelisa_alegrete@hotmail.com

\section{INTRODUCTION}

The breastfeeding practice has been widely discussed in Brazil and in the world. From the nutritional point of view, exclusive breastfeeding (EBF) is the most nutritious and adequate food for children until the first six months of life, for being rich in vitamins, proteins, carbohydrates, fats, minerals and water. These nutrients are crucial for children's growth and development. After this period, to satisfy infants' nutritional needs, the supplementary feeding (SF) should be initiated with the continuity of breastfeeding until two years of age or older ${ }^{(1)}$.

EBF until six months of age and, after this age, breastfeeding (BF) until two years of age or more, combined with suitable introduction of balanced SF are emphasized by the World Health Organization (WHO) as important measures that cause an effective impact on reducing the risk of developing chronic noncommunicable diseases (CNCD), as obesity, hypertension and diabetes mellitus, and promote physical and psychological health for the infant and the woman who breastfeeds ${ }^{(2)}$.

Although Brazil has advanced with regard to improvement of breastfeeding indicators ${ }^{(3)}$, there is a lot to evolve, especially if the aim is to accomplish the recommendation proposed by the $\mathrm{WHO}$, of having at least $50 \%$ of children in exclusive breastfeeding. For that, there must be intersectoral collective efforts aiming at implementing actions of protection and promotion of BF and appropriate $\mathrm{SF}$, within a perspective of integral and humanized approach ${ }^{(4)}$.

In this sense, the role of healthcare professionals is essential in the process, through actions on services directed to promotion, encouragement and support to BF and healthy SF. For that, the professional must be qualified and demonstrate safety for the mother regarding breastfeeding difficulties, assisting her in moments of anxiety and providing consistent information ${ }^{(5)}$.

However, this will only be possible when the action is based and instrumentalized on up-to-date technical and scientific knowledge. Thus, professionals' satisfactory knowledge about the subject are of utmost importance. Therein, studies have been evidencing a deficit of knowledge about this subject by professionals involved in providing health care to mothers, standing out the need for adequate preparation and commitment in breastfeeding promotion ${ }^{(6-7)}$.

Based on problematic exposed, the investment on permanent health education (EPS - Educação Permanente em Saúde) is mandatory when aiming at promoting a better communication with mothers and family members, so that they can discuss their needs, expectations, anxieties and choices as well as effectively contribute to the promotion of $\mathrm{BF}$ and $\mathrm{SF}^{(8)}$.

\section{OBJECTIVE}

To analyze the knowledge about BF and SF of professionals in the Primary Health Care working in the teams of the
Family Health Strategy (ESF - Estratégia Saúde da Família) of a municipality.

\section{METHOD}

\section{Ethical aspects}

This research was approved by the Research Ethics Committee of the Centro Universitário UNINOVAFAPI, according to resolution no. 466, from December $12,2012^{(9)}$, the National Council of the Brazilian Ministry of Health, approved on May 11, 2016. All participants signed the Informed Consent Form.

\section{Study design, location, and period}

Descriptive research with cross-sectional design conducted with professionals in the Primary Health Care team of the municipality of Picos (PI), Brazil. This is the third most important macroregion of Piauí, in populational and economic terms, consisting of 42 municipalities. The estimated population of this state was 368,877 inhabitants in $2016^{(10)}$.

\section{Population or sample, inclusion and exclusion criteria}

The study was carried out with Primary Health Care teams from June to September 2016. The Primary Health Care teams work in urban and rural areas and are linked to the Municipal Health Secretariat (Secretaria Municipal de Saúde) of Picos-PI, acting on the Brazilian Unified Health System (SUS). The municipality has 36 Primary Health Care teams, with distribution of 25 teams in urban areas and 11 in rural areas, totaling 296 healthcare professionals (36 doctors, 36 nurses, 36 nursing technicians and 188 community health agents).

The simple random sample was calculated having as basis of population the 296 professionals registered at the local government, totaling a sample of 168 respondents, with sampling error of 0.05 , according to Lewin's equation ${ }^{(11)}$. The distribution of professionals within the sample was conducted according to the ratio as a percentage of the body of Primary Health Care teams in Picos-PI (64\% community health agents, 12\% doctors, $12 \%$ nurses, $12 \%$ nursing technicians) to cover the populational reality. There was no refusal nor withdrawal of participants.

Inclusion criteria to the study consisted of being a healthcare professional working in the Primary Health Care of the municipality with at least one year of experience and providing the follow-up of women with children under two years old. Professionals on volunteering activities or internships and those on vacation or leave of absence were excluded from the study.

\section{Study protocol}

Data collection was conducted in morning and afternoon shifts by one of the researchers in a private place of the institution. The researcher was guided by an instrument adapted from 
previous studies ${ }^{(12-13)}$, being the new version evaluated by five experts in the area (face and content validation) and previously tested in pilot study. The instrument had 44 questions and was structured into two parts: the first aimed at identifying the profile of healthcare professionals and the second aimed at assessing their knowledge about the promotion of BF and healthy SF. At the end of each interview, the participant was questioned about his/her desire in remaining in the search or of changing the answers; however, there were no withdrawals nor changes. Data collection occurred from June to September 2016.

\section{Analysis of the results and statistics}

For the analysis, a database was built in the software Microsoft Office Excel 2016; in the next step, the database was imported and analyzed with the software Action Stat, version 3.0.2 $2^{(14)}$.

Data analysis considered the means and medians of the percentage of knowledge about BF and SF by professional category. The Shapiro-Wilk test was applied to evaluate the normality of quantitative variables. To compare the means of percentage regarding the knowledge about BF and SF by professional training, the Kruskal Wallis test was used with Tukey post hoc test.

Regarding the analysis of hits on knowledge of professionals of the ESF in promotion of BF and SF, the recommendations of the guidebook "Child health: breastfeeding and complementary feeding", of the Brazilian Ministry of Health ${ }^{(15)}$ were set as parameters.

To study the dependency between proportions of quantitative variables (age and service time), they were set as bicategorical, having as basis the median of results, because it is a central measure that is not distorted by high and low values; on the other hand, independent categorical variables with more than one category (education and profession) had the bicategorization set through Hosmer-Lemeshow test, which is based on the division of the sample into estimated parameters. As for the classification on the level of knowledge of professionals working in the Primary Health Care, the frequency of responses of all professionals about each aspect addressed of the variables of knowledge about BF and SF were considered. Criteria for classification were: good knowledge, when the percentage of hits ranged between $80 \%$ and $100 \%$; average, between $50 \%$ and $79.9 \%$; and poor, below $50 \%{ }^{(13)}$.

For the response variable on level of knowledge, the Chi-square test or the Fisher's exact test (if required) was used to study the dependence. Explanatory variables analyzed were categorized as follows: age ( $\leq 40$ years and $>40$ years); sex (male and female); service time ( $<15$ years and $\geq 15$ years); education ( $\leq$ high school and > high school); occupation (nursing technicians + community health agents and doctors + nurses); provides healthcare on BF (yes and no); had training/preparation on BF (yes and no); knows the Brazilian Breastfeeding and Feeding Strategy (EAAB - Estratégia Amamenta e Alimenta Brasil) (yes and no). Data were analyzed by the contingency coefficient (CC) to study the association between the level of knowledge and the variables for sociodemographic factors and professional training, according to the nature of the questions (BF and SF). Therefore, an $\alpha=0.05$ was set for all statistical tests as level for nullity rejection between associations.

\section{RESULTS}

A total of 168 ESF professionals participated in the study, being $112(66.67 \%)$ community health agents (CHA), $19(11.31 \%)$ nursing technicians, 20 (11.90\%) nurses and 17 (10.12\%) doctors. From the respondents, $87.50 \%$ are female and $12.50 \%$ are male, with age ranging between 23 and 63 years. Considering the total service time, a predominance of professionals with over 10 years of occupation $(71.43 \%)$ was noted. With regard to the respondent's educational level, $53.57 \%$ completed high school and $46.43 \%$ had higher education (Table 1 ).

Table 1 - Sociodemographic and professional characterization focused on health care to breastfeeding and supplementary feeding among professionals of the Family Health Strategy (ESF - Estratégia Saúde da Família), Picos, Piauí, Brazil, 2016

\begin{tabular}{|c|c|c|}
\hline Variables & $\mathbf{n}$ & $\%$ \\
\hline \multicolumn{3}{|l|}{ Age } \\
\hline 20 to 30 years & 24 & 14.29 \\
\hline 31 to 40 years & 50 & 29.76 \\
\hline 41 to 50 years & 64 & 38.10 \\
\hline$\geq 51$ years & 30 & 17.85 \\
\hline \multicolumn{3}{|l|}{ Sex } \\
\hline Female & 147 & 87.50 \\
\hline Male & 21 & 12.50 \\
\hline \multicolumn{3}{|l|}{ Service time } \\
\hline$<5$ years & 28 & 16.67 \\
\hline 5 to 9 years & 20 & 11.90 \\
\hline 10 to 14 years & 36 & 21.43 \\
\hline 15 to 19 years & 54 & 32.14 \\
\hline$\geq 20$ years & 30 & 17.86 \\
\hline \multicolumn{3}{|l|}{ Education level } \\
\hline High School & 90 & 53.57 \\
\hline Undergraduate education & 28 & 16.67 \\
\hline Specialization & 39 & 23.21 \\
\hline Master's degree course & 6 & 3.57 \\
\hline Doctor's degree course & 5 & 2.98 \\
\hline \multicolumn{3}{|l|}{ Profession } \\
\hline Doctor & 17 & 10.12 \\
\hline Nurse & 20 & 11.90 \\
\hline Nursing technician & 19 & 11.31 \\
\hline Community health agent & 112 & 66.67 \\
\hline \multicolumn{3}{|c|}{$\begin{array}{l}\text { Provides health care on breastfeeding to } \\
\text { lactating mothers }\end{array}$} \\
\hline No & 36 & 21.43 \\
\hline Yes & 132 & 78.57 \\
\hline \multicolumn{3}{|c|}{$\begin{array}{l}\text { Provides health care on supplementary feeding } \\
\text { to lactating mothers }\end{array}$} \\
\hline No & 43 & 25.60 \\
\hline Yes & 125 & 74.40 \\
\hline \multicolumn{3}{|c|}{ Had training/preparation on breastfeeding } \\
\hline No & 62 & 36.90 \\
\hline Yes & 106 & 63.10 \\
\hline \multicolumn{3}{|c|}{$\begin{array}{l}\text { Had training/preparation on supplementary } \\
\text { feeding }\end{array}$} \\
\hline No & 97 & 57.74 \\
\hline Yes & 71 & 42.26 \\
\hline
\end{tabular}


Table 1 (concluded)

\begin{tabular}{lcc}
\hline \multicolumn{1}{c}{ Variables } & $\mathbf{n}$ & $\mathbf{\%}$ \\
\hline Knows the Brazilian Breastfeeding and Feeding & & \\
$\begin{array}{l}\text { Strategy (EAAB) } \\
\text { No }\end{array}$ & 125 & 74.40 \\
Yes & 43 & 25.60 \\
\hline
\end{tabular}

When questioned about the health care on BF an SF, 78.57\% of respondents reported providing assistance on BF and $74.40 \%$ assist in SF. As for participation in training/preparation on BF and $\mathrm{SF}, 63.10 \%$ reported having had participated in training/ preparation on BF and $42.26 \%$ on SF. Regarding the knowledge of $E A A B, 74.40 \%$ claimed not knowing this program (Table 1 ).
Table 2 describes the means and medians of the percentage of hits in relation to ESF professionals' knowledge about $\mathrm{BF}$ and SF. Regarding the knowledge of breastfeeding, there was statistical difference between the means of percentages of hits of compared to the $\mathrm{CHA}(\mathrm{p}=0.01)$. Among nurses the hit ratio was $83 \%$, higher than the $\mathrm{CHA}(71.8 \%)$. In relation to the supplementary feeding, a statistically significant difference was noted between the means of proportion of hits of nursing technicians and $\mathrm{CHA}(\mathrm{p}<0.01)$. For nursing technicians, the mean of hits was $64.4 \%$; as for $\mathrm{CHA}$, this proportion was only $54.9 \%$. Considering the other categories, the means of proportions of hits was similar. It must be emphasized that, when the knowledge about BF was compared to the SF for each professional category, a statistically significant difference was noted between the means of hits, because all categories had higher mean of hits for BF compared to SF (Table 2).

Table 3 shows the results of the analysis of association between level of knowledge about breastfeeding and variables of sociodemographic factors and professionals' training. It is noted that there was significant statistical association between professionals' level of knowledge and variables: education level $(p=0.04)$, i.e., professionals who had education beyond high school had higher level of knowledge; occupation ( $p=0.05$ ), in which doctors and nurses had better level of knowledge about BF than other professionals in the Primary Health Care team; and those who provide assistance in BF to lactating mothers have a better level of knowledge of $B F(p=0.04)$. According to the contingency coefficient (CC) values, these three variables had moderate association (0.1 to 0.3 ) with the performance of participants of the study.

Note: probability value of Kruskal-Wallis test. P-values for differences of means by Tukey's test: *0.02. + 0.003. $\# 0.012 . * * 95 \% \mathrm{Cl}$ : Confidence interval of the mean.

Table 3 - Bivariate analysis between level of knowledge about breastfeeding and variables of sociodemographic factors and training of professionals in the Family Health Strategy (ESF - Estratégia Saúde da Família), Picos, Piauí, Brazil, 2016

\begin{tabular}{|c|c|c|c|c|c|c|c|c|}
\hline \multirow{2}{*}{ Variables } & \multicolumn{2}{|c|}{ Good } & \multicolumn{2}{|c|}{ Average } & \multicolumn{2}{|c|}{ Poor } & \multirow{2}{*}{$\mathrm{CC}^{1}$} & \multirow{2}{*}{$p^{2}$} \\
\hline & $\mathrm{n}$ & $\%$ & $\mathrm{n}$ & $\%$ & $\mathrm{n}$ & $\%$ & & \\
\hline \multicolumn{9}{|l|}{ Age } \\
\hline$\leq 40$ years & 31 & 18.5 & 38 & 22.6 & 5 & 2.98 & & \\
\hline$>40$ years & 35 & 20.8 & 55 & 32.7 & 4 & 2.38 & 0.08 & 0.58 \\
\hline \multicolumn{9}{|l|}{ Sex } \\
\hline Female & 59 & 35.1 & 81 & 48.2 & 7 & 4.17 & & \\
\hline Male & 7 & 4.17 & 12 & 7.14 & 2 & 1.19 & 0.07 & 0.6 \\
\hline \multicolumn{9}{|l|}{ Service time } \\
\hline$<15$ years & 38 & 22.6 & 44 & 26.2 & 2 & 1.19 & & \\
\hline$\geq 15$ years & 28 & 16.7 & 49 & 29.2 & 7 & 4.17 & 0.16 & 0.1 \\
\hline
\end{tabular}




\begin{tabular}{|c|c|c|c|c|c|c|c|c|}
\hline \multirow{2}{*}{ Variables } & \multicolumn{2}{|c|}{ Good } & \multicolumn{2}{|c|}{ Average } & \multicolumn{2}{|c|}{ Poor } & \multirow{2}{*}{$\mathrm{CC}^{1}$} & \multirow{2}{*}{$p^{2}$} \\
\hline & $\mathrm{n}$ & $\%$ & $\mathrm{n}$ & $\%$ & $\mathrm{n}$ & $\%$ & & \\
\hline \multicolumn{9}{|l|}{ Education level } \\
\hline$\leq$ High School & 28 & 16.7 & 55 & 32.7 & 7 & 4.17 & & \\
\hline$>$ High School & 38 & 22.6 & 38 & 22.6 & 2 & 1.19 & 0.19 & 0.04 \\
\hline \multicolumn{9}{|l|}{ Occupation* } \\
\hline Nursing technician and community health agent & 46 & 35.11 & 76 & 58.02 & 9 & 6.87 & & \\
\hline Doctors and nurses & 20 & 54.05 & 17 & 45.95 & 0 & 0 & 0.18 & 0.05 \\
\hline \multicolumn{9}{|l|}{ Provides health care on breastfeeding to lactating mothers } \\
\hline No & 13 & 7.74 & 18 & 10.7 & 5 & 2.98 & & \\
\hline Yes & 53 & 31.5 & 75 & 44.6 & 4 & 2.38 & 0.19 & 0.04 \\
\hline \multicolumn{9}{|l|}{ Had training/preparation on breastfeeding } \\
\hline No & 20 & 11.9 & 38 & 22.6 & 4 & 2.38 & & \\
\hline Yes & 46 & 27.4 & 55 & 32.7 & 5 & 2.98 & 0.11 & 0.35 \\
\hline \multicolumn{9}{|c|}{ Knows the Brazilian Breastfeeding and Feeding Strategy (EAAB) } \\
\hline No & 45 & 26.8 & 72 & 42.9 & 8 & 4.76 & & \\
\hline Yes & 21 & 12.5 & 21 & 12.5 & 1 & 0.6 & 0.13 & 0.25 \\
\hline
\end{tabular}

Note: ${ }^{1}$ Measure of association, with reference: $n \leq 0.1$ : weak or nonexistent association; $n=0.1$ to 0.3 : moderate association; $n \geq 0.3$ : strong association; ${ }^{2} P$-values for the Chi-square test with significance level $\leq 0.05 ;{ }^{*}$ The percentage of professionals was calculated in proportion to the total number of respondents by category in the table.

Table 4 displays the association between sociodemographic and training variables with the level of knowledge about $\mathrm{BF}$ in 168 healthcare professionals. According to the CC, the variable for educational level had strong association $(C C=0.34)$ with high level of statistical significance $(p<0.01)$; professionals who had educational level beyond high school had better level of knowledge and those who provided $\mathrm{BF}$ health care to lactating mothers have better level of knowledge about BF. This variable had moderate association $(C C=0.19)$ with significant $p$-value $(p=0.04)$.

Table 4 - Bivariate analysis between level of knowledge of breastfeeding and variables for sociodemographic factors and training of professionals in the Family Health Strategy (ESF - Estratégia Saúde da Família), Picos, Piauí, Brazil, 2016

\begin{tabular}{|c|c|c|c|c|c|c|c|c|}
\hline \multirow{2}{*}{ Variables } & \multicolumn{2}{|c|}{ Good } & \multicolumn{2}{|c|}{ Average } & \multicolumn{2}{|c|}{ Poor } & \multirow{2}{*}{$\mathrm{CC}^{1}$} & \multirow{2}{*}{$p^{2}$} \\
\hline & $\mathrm{n}$ & $\%$ & $\mathrm{~N}$ & $\%$ & $\mathrm{~N}$ & $\%$ & & \\
\hline \multicolumn{9}{|l|}{ Age } \\
\hline$\leq 40$ years & 1 & 0,6 & 57 & 33,9 & 16 & 9,52 & & \\
\hline$>40$ years & 3 & 1,79 & 76 & 45,2 & 15 & 8,93 & 0,09 & 0,5 \\
\hline \multicolumn{9}{|l|}{ Sex } \\
\hline Female & 3 & 1,79 & 119 & 70,8 & 25 & 14,9 & & \\
\hline Male & 1 & 0,6 & 14 & 8,33 & 6 & 3,57 & 0,12 & 0,3 \\
\hline \multicolumn{9}{|l|}{ Service time } \\
\hline$<15$ years & 2 & 1,19 & 69 & 41,1 & 13 & 7,74 & & \\
\hline$\geq 15$ years & 2 & 1,19 & 64 & 38,1 & 18 & 10,7 & 0,08 & 0,61 \\
\hline \multicolumn{9}{|l|}{ Education level } \\
\hline$\leq$ High School & 1 & 0,6 & 65 & 38,7 & 24 & 14,3 & & \\
\hline$>$ High School & 3 & 1,79 & 68 & 40,5 & 7 & 4,17 & 0,34 & $<0,01$ \\
\hline \multicolumn{9}{|l|}{ Occupation* } \\
\hline Nursing technician and community health agent & 2 & 1,53 & 101 & 77,1 & 28 & 21,37 & & \\
\hline Doctors and nurses & 2 & 5,41 & 32 & 86,5 & 3 & 8,11 & 0,17 & 0,09 \\
\hline \multicolumn{9}{|l|}{ Provides health care on breastfeeding to lactating mothers } \\
\hline No & 0 & 0 & 30 & 17,9 & 13 & 7,74 & & \\
\hline Yes & 4 & 2,38 & 103 & 61,3 & 18 & 10,7 & 0,19 & 0,04 \\
\hline \multicolumn{9}{|l|}{ Had training/preparation on breastfeeding } \\
\hline No & 1 & 0,6 & 44 & 26,2 & 17 & 10,1 & & \\
\hline Yes & 3 & 1,79 & 89 & 53 & 14 & 8,33 & 0,17 & 0,07 \\
\hline \multicolumn{9}{|c|}{ Knows the Brazilian Breastfeeding and Feeding Strategy (EAAB) } \\
\hline No & 4 & 2,38 & 96 & 57,1 & 25 & 14,9 & & \\
\hline Yes & 0 & 0 & 37 & 22 & 6 & 3,57 & 0,12 & 0,31 \\
\hline
\end{tabular}

Note: ${ }^{1}$ Measure of association, with reference: $n \leq 0.1$ : weak or nonexistent association; $n=0.1$ to 0.3 : moderate association; $n \geq 0.3$ : strong association; ${ }^{2} P$-values for the Chi-square test with significance level $\leq 0.05 ; *$ The percentage of professionals was calculated in proportion to the total number of respondents by category in the table. 


\section{DISCUSSION}

The analysis of knowledge about BF and SF of professionals working in the ESF showed a better performance on issues of $\mathrm{BF}$ in relation to SF. This finding is a matter of concern, since healthcare professionals must be prepared and trained to monitor the process of breastfeeding and introduction of supplementary foods, growth and development of the child, especially in the first two years of life, both in individual appointments and home visits. In addition, they must guide the women and their families with regard to the access to other services and support groups related to breastfeeding and supplementary feeding.

Furthermore, mothers need active and emotional support, as well as precise information, to feel confident. The healthcare professional must understand what kind of support, information and interaction the mothers desire, need or expect from him/her ${ }^{(16)}$.

In this sense, EAAB stands out as an important tool to aid achieving the goals regarding $\mathrm{BF}$ and $\mathrm{SF}$. This strategy was prepared by the Brazilian Ministry of Health, in 2012, and it is the main program focused on preparing the professionals working in the Primary Health Care for BF and SF. The program was launched with the purpose of training healthcare professionals based on participatory activities that allow exchange and acquisition of knowledge, taking into account the local reality to directly influence the breastfeeding indicators ${ }^{(17)}$. About this strategy, the knowledge of professionals was identified as insufficient, which reinforces the need for more information.

The knowledge of healthcare professionals proved to be associated with important variables of training and performance, in especial with the education level. Thus, this study showed that the higher the educational level, the better are the professional's conditions of incorporating new knowledge and abilities to assist the families under his/her responsibility.

This result may be related to the large number of professionals without higher education, as the $\mathrm{CHA}$ in the sample of our study. The emergence of Primary Health Care established the ability of reading and writing as minimum education criterion, without demanding a more technical and scientific knowledge based on the needs of people closer to and from the community. However, this may impair the performance of Primary Health Care, since a previous research has identified that, in relation to nutrition and feeding, $\mathrm{CHA}$ have insufficient knowledge to face the problems of their routine, presenting difficulties ranging from the practice of breastfeeding and supplementary feeding until the insufficient knowledge about which foods the child can consume in the first year of life. It is worth mentioning that this same research showed that $\mathrm{CHA}$ with higher education had higher ease in executing their duties ${ }^{(18)}$.

This finding reinforces the need for permanent education of professionals working in the Primary Health Care, regardless of their educational level, aiming at enabling the theoretical basis of their actions, making the latter more effective in the promotion of breastfeeding. On this matter, a study conducted in southern Brazil identified that the preparation in BF increased the hit scores of professionals compared with those who had no preparation ${ }^{(19)}$.

The scientific literature is categorical when stating that permanent education is a strategy to enhance the knowledge and practices aimed at management and care on feeding and nutritional actions, creating an opportunity to contribute to the reversal of the organizational logic based only on the disease. Permanent health education can guide the transformation of health promotion practices, aiming at changing the hegemonic conception of the biomedical model to a constructivist and problematizing conception, which favors the subject's participation in the actions of health and social mobilization ${ }^{(19-20)}$.

There is the need of better preparing healthcare professionals to work the actions of feeding and nutrition through constant training and continuous monitoring of these actions, identifying difficulties and providing conditions to overcome them, leading to their full development ${ }^{211}$.

The team planning of actions is important because it will directly influence the achievement of goals and, consequently, the improvement of the quality of service provision. To this end, the health education planning must not to be individualized because the integration of management, healthcare professionals and community, is crucial and uses varied tools and resources ${ }^{(22)}$.

To assist the collective approach of promotion practices for proper and healthy feeding by healthcare professionals, the Brazilian Government has recently launched an instrument aiming at supporting the planning and development of these actions in Primary Health Care. The project includes proposals of methodologies, in addition to the theoretical and practical basis for their development, as well as the publication of manuals and ordinances that address the principles and recommendations on $\mathrm{BF}$ and $\mathrm{SF}^{(23)}$.

Therefore, there is need for enabling courses and training programs that qualify these professionals on $\mathrm{BF}$ and on $\mathrm{SF}$, especially. To this end, actions of permanent health education are suggested, in a constant promotion process as well as full and contextualized development of teams. On this matter, the implementation of $E A A B$ in the municipality is recommended to qualify the professionals' working process and to strengthen the actions of promotion, protection and support to breastfeeding and supplementary feeding of children under two years old in the context of Primary Health Care. In addition, it can contribute to the improvement of indicators for breastfeeding and supplementary feeding.

\section{Study limitations}

This study presents some limitations. The main limitation is related to the methodological design used, of cross-sectional type, which does not allow to evaluate causal relations, as well as exposure and outcome related to the knowledge learned. Still, the fact that our research was held in a single municipality restricts the generalization of results. We also emphasize the possibility of information bias, since that, when acknowledging the research, the participants could have searched the correct information to avoid negative judgment.

Contributions to the fields of nursing, health, or public policy The nurse must be sensitive to his/her role with the woman during the pregnancy and puerperal cycle and; also, after patient discharge, the healthcare professional must assist the mother in the process of breastfeeding adaptation, thereby avoiding doubts, misunderstandings and other complications. As a member of the multidisciplinary health team, the nurse must perceive deficiencies and solve them when possible, contributing to a performance based on knowledge and skill focused on the mother and child ${ }^{(6-7)}$. 


\section{CONCLUSION}

This study verified that healthcare professionals working in the ESF have greater knowledge about breastfeeding when compared to knowledge of supplementary feeding. This finding was associated with important training (education level) and performance (health care on BF and SF provided by professionals to the lactating mothers) variables.

\section{REFERENCES}

1. Dias MCAP, Freire LMS, Franceschini SCC. Recomendações para alimentação complementar de crianças menores de dois anos. Rev Nutr[Internet]. 2010[cited 2017 Aug 18];23(3):475-86. Available from: http://www.scielo.br/pdf/rn/v23n3/15.pdf

2. Dattilo AM, Birch L, Krebs NF, Lake A, Taveras EM, Saavedra JM. Need for early interventions in the prevention of pediatric overweight: a review and upcoming directions. J Obesity[Internet]. 2012[cited 2017 Aug 18];2012:ID123023:[18 pages]. Available from: https://www.hindawi.com/journals/jobe/2012/123023/

3. Victora CG, Bahl R, Barros AJ, França GV, Horton S, Krasevec J, et al. Breastfeeding in the 21st century: epidemiology, mechanisms, and lifelong effect. Lancet[Internet]. 2016[cited 2017 Aug 18];387(10017):475-90. Available from: https://dx.doi.org/10.1016/ S0140-6736(15)01024-7

4. Sousa AM, Fracolli LA, Zoboli ELCP. Práticas familiares relacionadas à manutenção da amamentação: revisão da literatura e metassíntese. Rev Panam Salud Publica[Internet]. 2013[cited 2017 Aug 18];34(2):127-34. Available from: https://www.scielosp. org/pdf/rpsp/2013.v34n2/127-134/pt

5. Dodt RCM, Oriá MOB, Pinheiro AKB, Almeida PC, Ximenes LB. Epidemiological profile of postpartum women receiving roomingin care. Rev Enferm UERJ[Internet]. 2010[cited 2017 Aug 18];18(3):345-51. Available from: http://www.facenf.uerj.br/v18n3/ v18n3a02.pdf

6. Fonseca-Machado MO, Haas VJ, Stefanello J, Nakano AMS, Gomes-Sponholz F. Breastfeeding: knowledge and practice. Rev Esc Enferm USP[Internet]. 2012[cited 2017 Nov 03];46(4):809-15. Available from: http://www.scielo.br/pdf/reeusp/v46n4/en_04.pdf

7. Magalhães CP, Rodrigues AM. Conhecimento de profissionais de saúde sobre aleitamento materno em um Hospital Universitário do Vale do Paraíba (SP). Rev Ciênc Hum[Internet]. 2014[cited 2017 Nov 03];7(1):72-86. Available from: https://www.rchunitau. com.br/index.php/rch/article/viewFile/123/71

8. Gonçalves LC, Cortez EA, Cavalcanti ACD. Permanent education in relation to Family Health Strategy: a descriptive-exploratory study. OBJN[Internet]. 2013[cited 2017 Aug 18];12(Suppl):593-5. Available from: http://www.objnursing. uff.br/index.php/nursing/ article/view/4528

9. Brasil. Ministério da Saúde. Resolução n 466, de 12 de dezembro de 2012[Internet]. Diário Oficial da União. 2012 Dec 12[cited 2018 Aug 21]. Available from: http://bvsms.saude.gov.br/bvs/saudelegis/cns/2013/res0466 1212 2012.html

10. Brasil. Instituto Brasileiro de Geografia e Estatística-IBGE. Estimativas da população residente no Brasil e unidades da Federação com data de referência em $1^{\circ}$ de julho de 2016[Internet]. 2016[cited 21 Aug 2018]. Available from: http://www.ibge.gov.br/home/ estatistica/populacao/estimativa2016/estimativa tcu.shtm.

11. Levin J. Estatística aplicada a ciências humanas. 2. ed. São Paulo: Harbra; 1987.

12. Matos RAC. Alimentação complementar em lactentes após aleitamento materno exclusivo: práticas e orientações[Dissertação]. Brasília, DF: Universidade de Brasília; 2011.

13. Silvestre PK, Carvalhaes MABL, Venâncio SI, Tonete VLP, Parada CMGL. Breastfeeding knowledge and practice of healthcare professionals in public health care services. Rev Latino-Am Enfermagem[Internet]. 2009[cited 2017 Aug 18];17(6):953-60. Available from: http://www.scielo.br/pdf/rlae/v17n6/05.pdf

14. Equipe Estatcamp. Software Action. Estatcamp: Consultoria em Estatística e Qualidade, São Carlos - SP, Brasil[Internet]. 2017[cited 2017 Aug 18]. Available from: http://www.portalaction.com.br/

15. Brasil. Ministério da Saúde. Secretaria de Atenção à Saúde. Departamento de Atenção Básica. Saúde da criança: nutrição infantil: aleitamento materno e alimentação complementar[Internet]. Brasília: Ministério da Saúde; 2009[cited 2017 Aug 18]. Available from: http://bvsms.saude.gov.br/bvs/publicacoes/saude_crianca_nutricao_aleitamento_alimentacao.pdf

16. Brown A. Maternal trait personality and breastfeeding duration: the importance of confidence and social support. J Adv Nurs[Internet]. 2014[cited 2017 Aug 18];70(3):587-98. Available from: https://www.ncbi.nlm.nih.gov/pmc/articles/PMC4114133/

17. Brasil. Ministério da Saúde. Portaria $n^{\circ}$ 1.920, de 5 de setembro de 2013. Institui a Estratégia Nacional para Promoção do Aleitamento Materno e Alimentação Complementar Saudável no Sistema Único de Saúde (SUS) - estratégia Amamenta e Alimenta Brasil[Internet]. Diário Oficial da União. 2013[cited 2014 Oct 16]:Seção 1. Available from: http://bvsms.saude.gov.br/bvs/saudelegis/ gm/2013/prt1920_05_09_2013.html

18. Ávila MMM. A case study of the Community Health Agents Program in Uruburetama, Ceará (Brazil). Ciênc Saúde Colet[Internet]. 2011[cited 2017 Aug 18];16(1):349-60. Available from: http://dx.doi.org/10.1590/S1413-81232011000100037

19. Vasquez J, Dumith SC, Susin LR. Maternal breastfeeding: a comparative study of knowledge and management among Family 
Health Strategy professionals and those using the traditional model. Rev Bras Saúde Mater Infant[Internet]. 2015 [cited 2017 Aug 18];15(2):181-92. Available from: http://dx.doi.org/10.1590/S1519-38292015000200004.20

20. Ricardi LM, Sousa MF. Ongoing food and nutrition education within the family health strategy: points of agreement and disagreement in major Brazilian cities. Cienc Saúde Colet[Internet]. 2015[cited 2017 Aug 18];20(1):209-18. Available from: http://dx.doi. org/10.1590/1413-81232014201.20812013.

21. Vasconcelos ACCP, Magalhães R. Práticas educativas em Segurança Alimentar e Nutricional: reflexões a partir da experiência da Estratégia Saúde da Família em João Pessoa, PB, Brasil. Interface[Internet]. 2016[cited 2018 Feb 04];20(56):99-110. Available from: http://www.scielo.br/pdf/icse/v20n56/1807-5762-icse-1807-576220150156.pdf

22. Roecker S, Nunes EFPA, Marcon SS. O trabalho educativo do enfermeiro na Estratégia Saúde da Família. Texto Contexto Enferm[Internet]. 2013[cited 2017 Aug 18];22(1):157-65. Available from: http://www.scielo.br/pdf/reeusp/v46n3/en_16.pdf

23. Vítolo MR, Louzada ML, Rauber F, Grechi P, Gama CM. The impact of health workers' training on breastfeeding and complementary feeding practices. Cad Saúde Pública[Internet]. 2014[cited 2017 Aug 18];30(8):1695-707. Available from: http://dx.doi. org/10.1590/0102-311X00186913 